\title{
Assessment of the hydrocarbon potentiality of the Late Jurassic formations of NW Iraq: A case study based on TOC and Rock-Eval pyrolysis in selected oil-wells
}

https://doi.org/10.1515/geo-2019-0071

Received Sep 10, 2018; accepted Feb 16, 2019

Abstract: The Late Jurassic Naokelekan and Barsarin formations of northwestern Iraq have been investigated in three wells to assess their potentiality for hydrocarbon generation.

The results of Total Organic Carbon content (TOC) and Rock-Eval Pyrolysis reveal fair to excellent content of hydrocarbon and suggest that the depositional conditions were suitable for the production and preservation of organic matter. The Thermal Maturity Proxy indicates that the studied formations were mature stage of hydrocarbon generation, with an exception of three samples from the Naokelekan Formation in Shaikhan-8 well, and two samples from the Barsarin Formation in Atrush-1 and Shaikhan- 8 wells were at an immature stage.

The $S_{1}$ and TOC relationship shows that all the samples are indigenous in nature. Most of samples from the Naokelekan Formation belong to kerogen Type II/III, and that in the Barsarin Formation belongs to kerogen Type II is dominant.

The $\mathrm{Pr} / \mathrm{Ph}, \mathrm{Pr} / \mathrm{n}-\mathrm{C}_{17}$ and $\mathrm{Ph} / \mathrm{n}-\mathrm{C}_{18}$ ratios for the extracted bitumen of both the formations indicate that they were originated from marine organic matter under reducing conditions. The $\delta^{13} \mathrm{C}_{S a t}$ and $\delta^{13} \mathrm{C}_{\text {Aro }}$ range from -28.7 to $-27.7 \%$ and -28.8 to $-27.7 \%$ respectively. These biomarkers show high contribution of marine organic matters preserved under relatively anoxic conditions in the studied formations.

Keywords: Naokelekan Fm., Barsarin Fm., Mangesh, Atrush, Shaikhan, Rock-Eval, Biomarker

\footnotetext{
^Corresponding Author: Swar J. Al-Atroshi: Department of Geology, College of Science, Salahaddin University-Erbil-Iraq;

Email: swarjamal@gmail.com; Tel: +964-7504661455

Govand H. Sherwani: Department of Civil Engineering, College of Engineering, Cihan University-Iraq;

Email: govand.sherwani@mhe-krg.org
}

\section{Introduction}

Many hydrocarbon fields have been discovered in deeper Jurassic reservoirs of the northwestern part of Iraq in the recent years, such as Tawki, Atrush, Swara Tika and Shaikhan fields. The Jurassic period represents a separate and distinct petroleum systems much distinct from those of the Triassic systems, in that they their independent internal source rocks, reservoirs, and regional seals [1, 2].

Atrush and Shaikhan oil fields are located in the High Folded Zone which is part of the Zagros Fold and Thrust Belt of Iraq, some $85 \mathrm{~km}$ northwest and $60 \mathrm{~km}$ north of Erbil city respectively. Both are recent oil discoveries in the Kurdistan Region of Iraq. The Atrush structure is a NWSE oriented, doubly-plunged asymmetrical anticline, and its northeastern limb is gentler than the southwestern one. The dip of the steeper forelimb may reach $>70^{\circ}$, and is overturned in some localities [3].

The Shaikhan anticline is a WNW-ESE trending, doubly-plunged asymmetrical anticline with a gentle southwestern limb and steeper backlimb. Consequently, this anticline is verging towards the northeast (hinterland). Furthermore, the attitude of the fold axis is $275^{\circ} / 5^{\circ}$, and the anticline is plunging $5^{\circ}$ towards WNW. This fold is considered as an open structure due to its interlimb angle of $120^{\circ}[4]$.

The Late Jurassic Naokelekan and Barsarin formations were first described by [5] from outcrops in the BalamboTanjero Zone at Naokelekan and Barsarin Villages in NE Iraq. The Naokelekan Formation conformably overlies the Sargelu Formation [6], and its upper contact with the Barsarin Formation is frequently marked by a detrital, ferruginous horizon in north Trust Zone [7]. The upper contact of Barsarin Formation with Chia Gara is conformable in the type area [5].

Srood F. Al-Naqshbandi: Department of Geology, College of Science, Salahaddin University-Erbil-Iraq; Email: sroodfn@gmail.com 


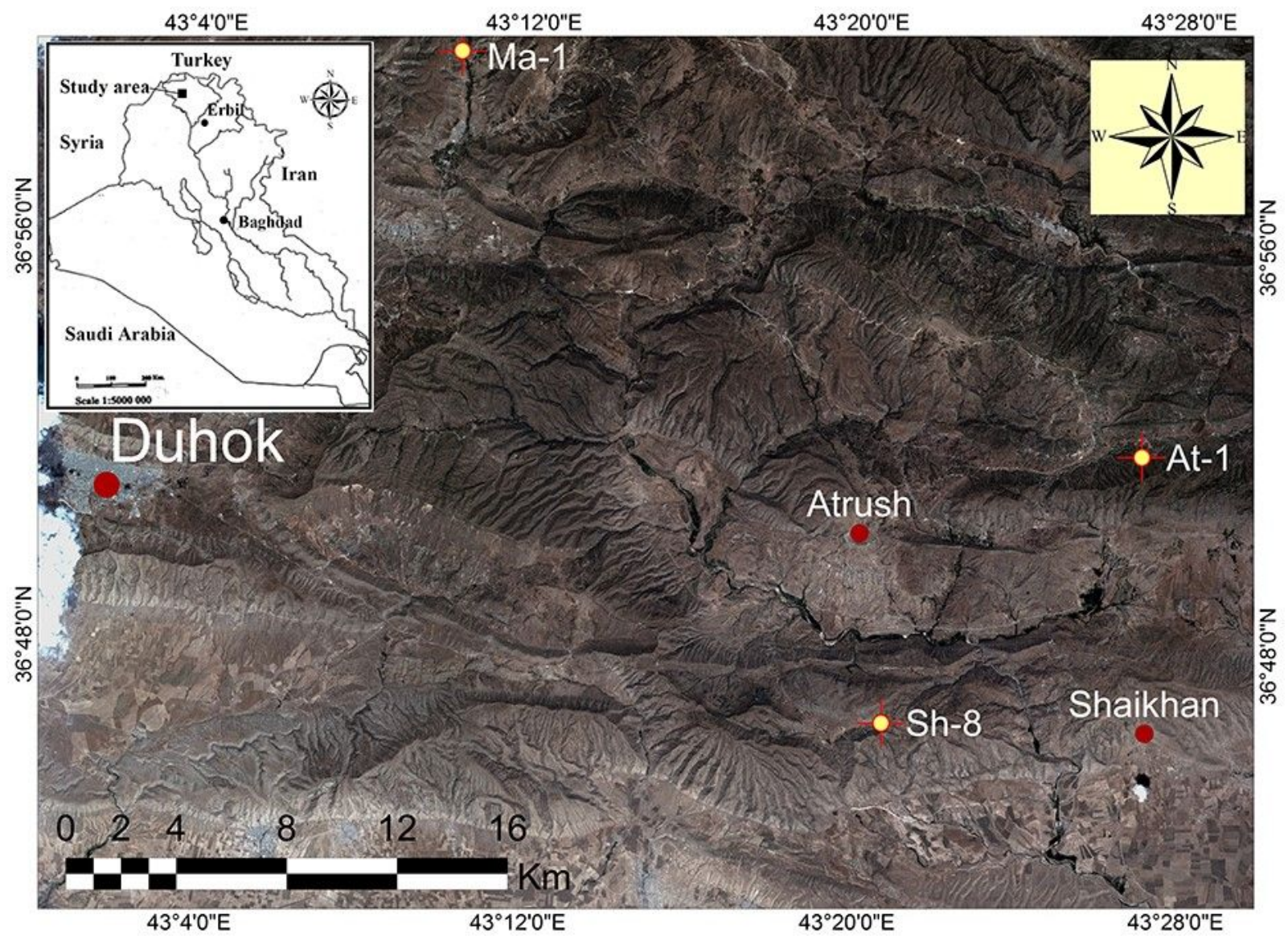

Figure 1: Landsat image showing the locations of the studied wells, Ma-1, At-1 and Sh-8

The Upper Callovian-Lower Oxfordian, with Kimeridgian and Oxfordian ages were suggested for Naokelekan and Barsarin source rocks in North Iraq respectively [8]. This was based on the study of Palynomorphs, mainly dinoflagellate cysts. Whereas, the age of Naokelekan Formation in Iraqi Kurdistan was indicated as Callovian to Upper Oxfordian based on the presence of Cyclagelosphaera deflandrei sp. and lotharingius sp. [9]. The amount of Total Organic Carbon (TOC) of the Naokelekan Formation decreases toward west, north, and southeastern parts of Iraqi Kurdistan ranging between 0.4 to $18.8 \mathrm{wt} . \%$, [10] and that the types II and III kerogens are the main components of organic matter [10, 11].

This study is the first one conducted on Mangesh-1 (Ma1), Atrush-1 (At-1) and Shaikhan-8 (Sh-8) wells (Figure 1). Although Naokelekan and Barsarin formations are consider as important sources of hydrocarbons in the northern Iraq basins, there are lack subsurface studies on the formations in northwestern Iraq. The objective being assessment of the TOC content and kerogen type characterization, along with determination of its maturity stage in order to deduce the genetic potential (GP). Furthermore, the depositional conditions of Late Jurassic Naokelekan and Barsarin formations are being studied by integrating organic geochemical data and molecular characterization.

\section{Geological Setting of Late Jurassic Period/Formations}

The Jurassic period in Iraq invariably includes the Late Toarcian-Early Tithonian Megasequence (AP7) spatially and temporally. There are several genetically related sequence packages that were deposited during this period.

The geological successions exposed within the studied well-sections include Jurassic Alan, Sargelu, Naokelekan and Barsarin formations from the oldest to youngest. Younger Cretaceous units are comprised of Chia Gara, Garagu, Sarmord, Qamchuqa, Kometan, Wajna, and Aqra formations. These were further overlain by the Tertiary succession comprised of Kolosh, Gercus and Pila Spi formations (Figure 2). 


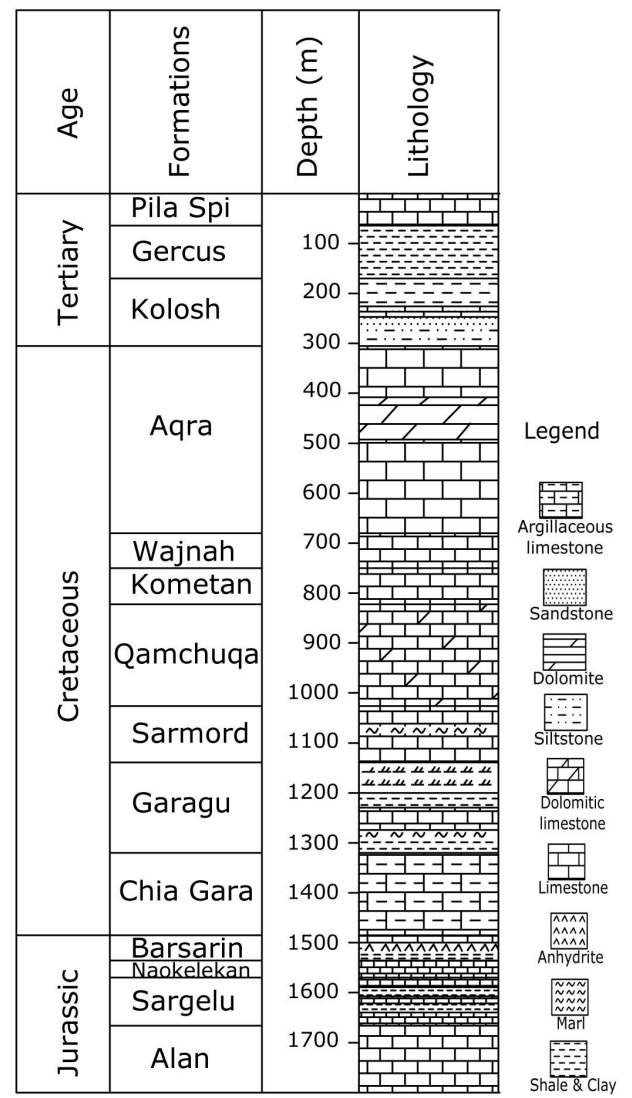

Figure 2: Stratigraphic column of Sh-8 well with a summary of lithology

Naokelekan Formation overlies Sargelu Formation and the represented contact between them is conformable [5]. The upper contact, of which is also conformable with the Barsarin Formation, is frequently marked by a detrital, ferruginous horizon in north Thrust Zone [7].

The lithology of Naokelekan Formation from bottom to top in the studied wells consists of:

- Argillaceous limestone, light to medium to dark grey, occasionally brownish grey, firm blocky, hard in part, subangular to angular, brittle, microcrystalline, slightly dolomitic.

- Pale grey-brown limestone, rarely dark grey-brown, hard, brittle, sub-blocky to angular microcrystalline, argillaceous in part, slightly dolomitic.

- Calcareous claystone, which is very dark grey to brownish grey, rarely black, moderately hard, subblocky to angular, carbonaceous (Figure 3).

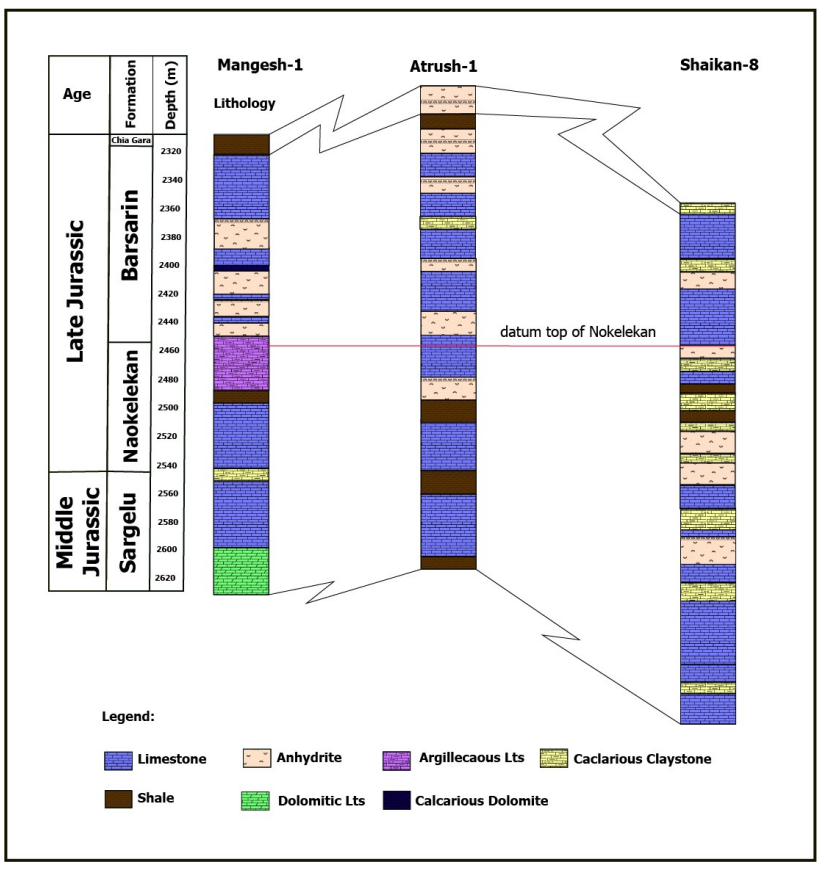

Figure 3: Lithologic description of the studied formations in Ma-1, At- 1 and Sh- 8 wells

Barsarin Formation conformably overlies Naokelekan Formation and conformably underlies Chia Gara Formation in the type area [5] and the studied wells.

The lithologic composition of Barsarin Formation from bottom to top in the studied wells, consists of:

- Snowy white anhydrite, soft occasionally firm.

- Limestone, medium to dark brown in color, moderately to very hard, brittle, blocky to angular, firm to moderately hard, blocky, crumbly, slightly argillaceous.

- Shale, light grey to dark grey, brownish, moderate soft to moderate hard, fragile and fissile.

- Claystone, predominantly light grey, soft, amorphous, occasionally grading medium grey, moderately hard.

- Dolomite, medium to dark brown in color, hard, brittle, blocky to angular (Figure 3).

The area of the High Folded Zone of Iraq including, Balambo-Tanjero and Northern Thrust Zones is characterized by condensed sedimentary successions of euxinic environment in the lower part (Naokelekan Formation), and lagoonal evaporites in the upper part (Barsarin Formation). This in turn led [12] to confer the presence of a tectonic ridge separating the basin in northern Iraq.

The available palaeogeographic maps for Late Jurassic demonstrate that the entire area was influenced by tectonic load along the Arabian Plate margin prior to the 
Table 1: Details of the cutting samples collected from Naokelekan and Barsarin formations in Iraqi Kurdistan for Rock-Eval pyrolysis

\begin{tabular}{ccccc}
\hline Well name & Formations & Number of samples & Formation thickness $(\mathrm{m})$ & Deposition $(\mathrm{Ma}) \mid$ \\
\hline Ma-1 & Barsarin & 3 & 138 & $153-146$ \\
& Naokelekan & 4 & 92 & $164-153$ \\
At-1 & Barsarin & 2 & 77 & $153-146$ \\
& Naokelekan & 1 & 7 & $164-153$ \\
Sh-8 & Barsarin & 2 & 51 & $153-146$ \\
& Naokelekan & 3 & 34 & $164-153$ \\
\hline
\end{tabular}

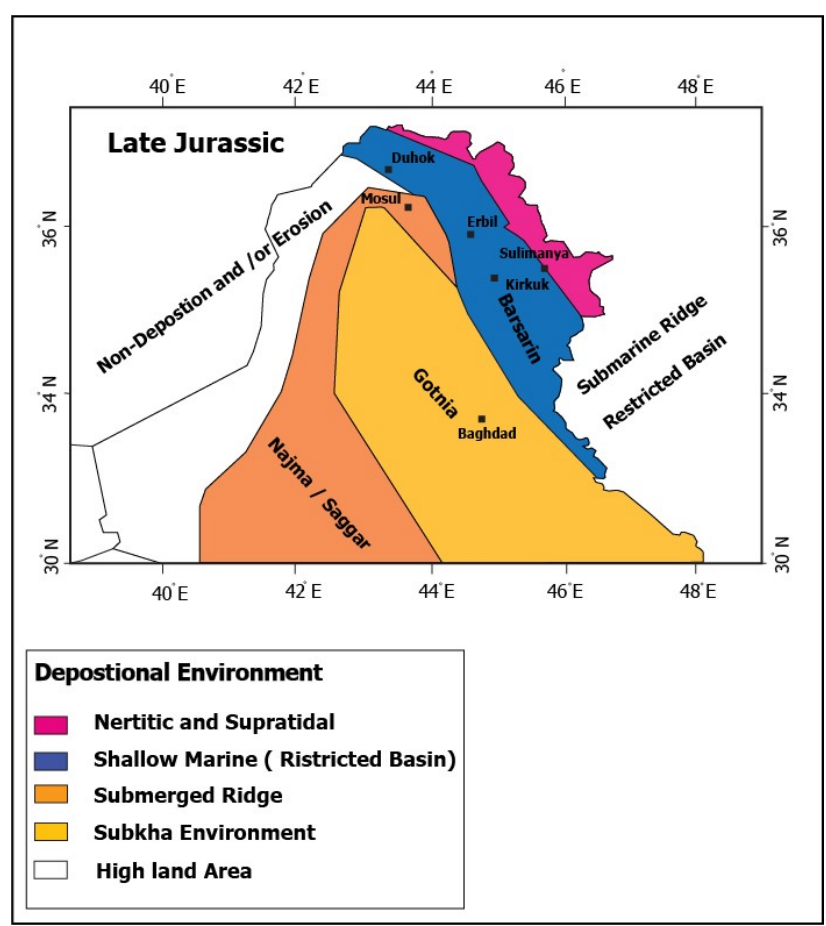

Figure 4: Palaeogeographic map of Late Jurassic period (modified after [1])

opening of the southern Neo-Tethys. Compartmentalization of intra- shelf basin subsidence caused the basin break up and split from Neo-Tethys [1]. Three main types of prominent facies along with their depositional environments are recognized: (1) a clastic-carbonate amalgamation setting, is indicative of the inner carbonate shelf (submerged ridge), represented by the Najmah and Saggar formations; (2) a carbonate-evaporite setting, is indicative for inner shelf (sabkha), represented by the Najmah and Gotnia formations; and (3) a restricted basin setting, denoted by the Naokelekan, Barsarin and Gotnia formations (Figure 4).

A large-scale intrashelf basin, termed Gotnia Basin, was formed in Iraq at the end of Early Jurassic. This basin occupied most of the southern, central, northern and northeastern Iraq and was relatively isolated from the open-marine waters of Tethys. It was highly restricted in Mid- to Late-Jurassic period, resulting in the deposition of rich source rocks and evaporites. The margins of the basin were probably controlled by a system of conjugate NW-SE and SW-NE trending lineaments [2].

\section{Sampling and Analytical Techniques}

A total of 15 well cutting samples were collected from shale and bituminous limestones within the Naokelekan and Barsarin formations (Table 1). All the samples were analyzed at the Geological Survey Repository Facility in ErbilIraq.

The TOC (wt.\%) was determined using a Buchner funnel and LECO C230 analyzer. The studied rocks were analyzed by Rock Eval pyrolysis method which estimates the $\mathrm{GP}\left(\mathrm{GP}=\mathrm{S}_{1}+\mathrm{S}_{2}\right.$, in $\mathrm{Kg} \mathrm{HC} /$ Ton rock) of rock samples using Rock-Eval 6 apparatus, according to a programmed temperature pattern. This was followed by heating the samples to $850^{\circ} \mathrm{C}$ at rate of $25^{\circ} \mathrm{C} / \mathrm{min}$ in an oxidation oven in the presence of air to oxidize the residual carbon $[13,14]$. The released hydrocarbons were monitored by Flame Ionization Detector (FID), generating two distinct peaks, $\mathrm{S}_{1}$ (thermally distilled free hydrocarbons in $\mathrm{mg} \mathrm{HC/g}$ of rock) and $\mathrm{S}_{2}$ (hydrocarbons released from the cracking of kerogen in $\mathrm{mg} \mathrm{HC} / \mathrm{g}$ of rock). In addition, carbon dioxide $\left(\mathrm{CO}_{2}\right)$ released during pyrolysis was monitored in real time by IR cell $\mathrm{S}_{3}$ (in $\mathrm{mg} \mathrm{CO}_{2} / \mathrm{g}$ of rock), giving information on the oxidation state of the kerogen. The temperature at the $\mathrm{S}_{2}$ peaks is called $\left(\operatorname{Tmax}\right.$ in $\left.{ }^{\circ} \mathrm{C}\right)$, which gives an indication of kerogen maturity. $\mathrm{T}_{\max }$ can also be used to calculate Vitrinite Reflectance $\left(\mathrm{R}_{o}\right)$ which is mathematically expressed by [15] as $\mathrm{R}_{o}$ (calculated $)=\left(0.018 \times \mathrm{T}_{\max }\right)-7.16$

Other diagnostic ratios have been calculated from the $\mathrm{S}_{1}, \mathrm{~S}_{2}, \mathrm{~S}_{3}$ and TOC such as Production Index $\left(\mathrm{PI}=\mathrm{S}_{1} / \mathrm{GP}\right)$, Hydrogen Index $\left(\mathrm{HI}=\mathrm{S}_{2} / \mathrm{TOC} \times 100\right.$, in $\left.\mathrm{mg} \mathrm{HC} / \mathrm{g} \mathrm{TOC}\right)$ and Oxygen Index (OI $=\mathrm{S}_{3} / \mathrm{TOC} \times 100$, in $\mathrm{mg} \mathrm{CO} / \mathrm{g}$ TOC). Pyrol- 
Table 2: Results of Rock-Eval pyrolysis for the samples from Ma-1, Atr-1 and Sh-8 wells

\begin{tabular}{ccccccccccccc}
\hline $\begin{array}{c}\text { Well } \\
\text { name }\end{array}$ & Formation & $\begin{array}{c}\text { Depth } \\
(\mathrm{m})\end{array}$ & $\begin{array}{c}\text { TOC } \\
\text { Wt.\% }\end{array}$ & $\mathrm{S}_{1}$ & $\mathrm{~S}_{2}$ & $\mathrm{~S}_{3}$ & $\begin{array}{c}\mathrm{T}_{\max } \\
{ }^{\circ} \mathrm{C}\end{array}$ & $\mathrm{HI}$ & $\mathrm{OI}$ & $\mathrm{PI}$ & $\mathrm{GP}$ & $\mathrm{R}_{o} \%$ \\
\hline Ma-1 & Barsarin & 2319 & 1.49 & 1.06 & 6.92 & 0.61 & 430 & 464 & 41 & 0.13 & 7.98 & 0.58 \\
& Barsarin & 2397 & 0.98 & 0.62 & 2.40 & 0.58 & 437 & 245 & 59 & 0.21 & 3.02 & 0.71 \\
& Barsarin & 2448 & 13.00 & 3.14 & 52.48 & 0.80 & 442 & 404 & 6 & 0.06 & 55.62 & 0.8 \\
& Naokelekan & 2463 & 6.07 & 2.11 & 22.09 & 0.90 & 437 & 364 & 15 & 0.09 & 24.2 & 0.71 \\
& Naokelekan & 2484 & 1.10 & 0.54 & 3.94 & 0.64 & 436 & 358 & 58 & 0.12 & 4.48 & 0.69 \\
& Naokelekan & 2502 & 1.05 & 0.36 & 3.02 & 0.93 & 433 & 288 & 89 & 0.11 & 3.38 & 0.63 \\
& Naokelekan & 2544 & 0.52 & 0.28 & 1.59 & 0.54 & 434 & 306 & 104 & 0.15 & 1.87 & 0.65 \\
At-1 & Barsarin & 1160 & 0.78 & 0.90 & 3.97 & 0.32 & 427 & 512 & 41 & 0.18 & 4.87 & 0.53 \\
& Barsarin & 1180 & 1.59 & 0.87 & 8.06 & 0.42 & 433 & 507 & 26 & 0.10 & 8.93 & 0.63 \\
& Naokelekan & 1210 & 1.57 & 1.00 & 7.86 & 0.38 & 432 & 501 & 24 & 0.11 & 8.86 & 0.62 \\
Sh-8 & Barsarin & 1495 & 3.13 & 1.22 & 16.70 & 1.03 & 429 & 534 & 33 & 0.07 & 17.92 & 0.56 \\
& Barsarin & 1509 & 2.36 & 1.33 & 12.99 & 0.70 & 434 & 550 & 30 & 0.09 & 14.32 & 0.65 \\
& Naokelekan & 1542 & 0.90 & 0.25 & 2.08 & 1.04 & 427 & 232 & 116 & 0.11 & 2.33 & 0.53 \\
& Naokelekan & 1557 & 1.18 & 0.24 & 3.33 & 0.91 & 429 & 282 & 77 & 0.07 & 3.57 & 0.56 \\
& Naokelekan & 1569 & 1.24 & 0.36 & 3.89 & 1.25 & 428 & 314 & 101 & 0.08 & 4.25 & 0.54 \\
\hline
\end{tabular}

ysis data were recorded with an aim to characterize the organic richness, kerogen type, petroleum generation potentiality and their thermal maturity $[13,14,16,17]$.

Gas chromatography (GC) was prepared to measure the abundance of alkane peak introduced by syringe into capillary column pursued by ionization during a controlled period. Six rock extracts were fractionated and analyzed in a similar fashion to the oils using Hewlett Packard HP 6890 Series II GC gas chromatograph. Stable carbon isotopic composition of the saturate and aromatic hydrocarbon fractions was determined, and the branched/cyclic fractions were analyzed by GC and Gas chromatographyMass Spectrometry (GC-MS).

The samples of Naokelekan and Barsarin formations in the three studied wells were performed by StratoChem Cervices, New Maadi Cairo, Egypt.

\section{Results and Discussion}

\subsection{Hydrocarbon potential}

The hydrocarbon potential of Naokelekan and Barsarin formations in Ma-1, At-1 and Sh-8 wells was determined from Rock Eval data (Table 2). Several parameters were examined for extracting the thermal maturity of the possible source rocks. Quality of organic matter (OM) determines whether the kerogen is oil-prone (Type I and II) or gasprone (Type III), [14].
The $S_{1}$ versus TOC plot provides the conclusive evidence about the origin of hydrocarbon present, whether it is indigenous (autochthonous) or non-indigenous (allochthonous), [18]. Figure 5 elucidates that all the analyzed samples from Ma-1, At-1 and Sh-8 wells lie below the inclined line (not migrated), and most of them have high TOC relative to low $S_{1}$ values, indicating their indigenous origin and free from contamination.

The measured $\mathrm{T}_{\max }$ values ranging between $427^{\circ} \mathrm{C}$ and $442^{\circ} \mathrm{C}$ indicate that all the samples were thermally maturated early [19]. Similarly, the OI values ranging from 6 to $166 \mathrm{mg} \mathrm{CO} / \mathrm{g}$ rock, are $<200 \mathrm{mg} \mathrm{CO} / \mathrm{g}$ rock, which indicates that there is no intensive weathering or mineral decomposition in analyzed rock samples [20]. Calculated $\mathrm{R}_{o}$ values ranging between 0.53 and $0.80 \%$, corresponds to the onset of oil generation (Table 2).

The pyrolysis data (HI vs $\mathrm{T}_{\max }$ ) indicates that most of the analyzed samples from the Naokelekan Formation are limited to the mature and immature zones of mixed Type II-III, whereas most of samples from the Barsarin Formation fall within the mature field of kerogen Type II (Figure 6). This also corresponds to their $\mathrm{HI}$ and $\mathrm{T}_{\max }$ values that range from 245 to $550 \mathrm{mg} \mathrm{HC} / \mathrm{g}$ TOC, and 427 to $442^{\circ} \mathrm{C}$ respectively (Table 2). This suggests that the Naokelekan Formation in Ma-1 and At-1 wells are more likely to be gas prone, while Barsarin Formation in the same wells have limited capacity to generate liquid hydrocarbons.

TOC content of the studied samples ranges from 0.52 to $6.07 \mathrm{wt} \%$ and 0.78 to $13.00 \mathrm{wt} \%$ with an average of $1.7 \mathrm{wt} \%$ and $3.3 \mathrm{wt} \%$ for the Naokelekan and Barsarin formations, 


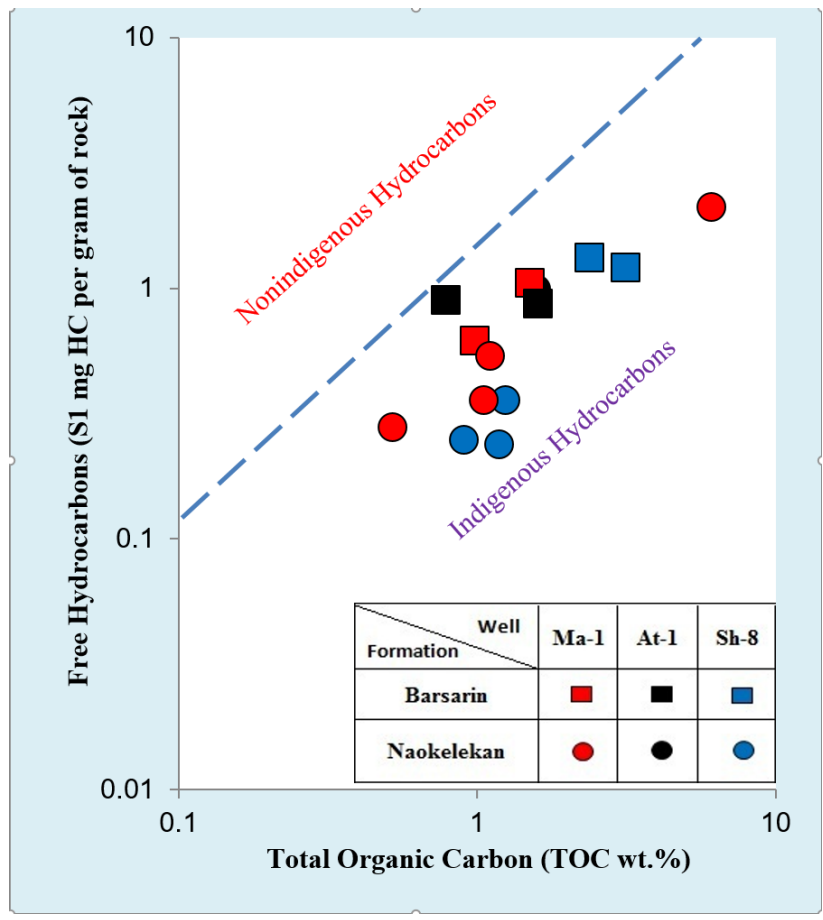

Figure 5: Plot of Total Organic Carbon (TOC) versus $S_{1}$ for the identification of migrated hydrocarbons of Naokelekan and Barsarin formations samples

respectively, indicating fair to excellent organic-richness (Table 2). The variation in TOC of Naokelekan and Barsarin formations from one well to another are due to the change of the environmental conditions that produced different lithologies. A number of samples from the Naokelekan Formation are rated in TOC higher than the rating depending on $\mathrm{S}_{2}$, probably due to some oxidized and/or reworked $\mathrm{OM}$ within different depositional environments (Figure 7).

A plot of $\mathrm{S}_{2}$ versus TOC demonstrates that most samples from both formations are Type II, Kerogen and prone to different levels of oil and gas (Figure 8). These results were supported by the previous work that performed by [21].

\subsection{Gas chromatographic analysis}

Six cutting samples from Naokelekan and Barsarin formations were chosen belonging to Ma-1, At- 1 and Sh- 8 wells to carry out the geochemical parameters of isoprenoid hydrocarbons, i.e., pristane $(\mathrm{Pr})$ and phytane $(\mathrm{Ph})$, that could act as indicators of the depositional environments (Table 3). Carbonate source rocks which were deposited in a reduced or anoxic depositional environment have $<2 \mathrm{Pr} / \mathrm{Ph}$ value [15]. The higher $\mathrm{Ph}$ content and lower $\mathrm{Pr} / \mathrm{Ph}$ ratio is

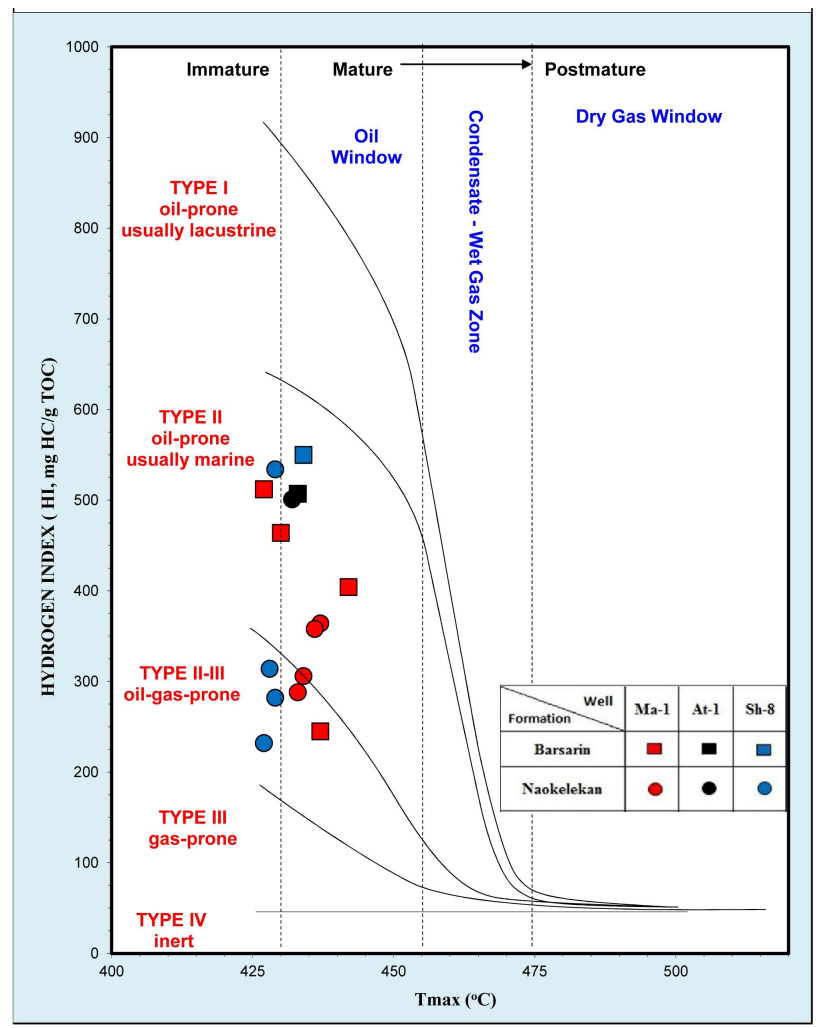

Figure 6: Plot of Hydrogen Index (HI) versus (Tmax) for the analysis of samples of Naokelekan and Barsarin formations

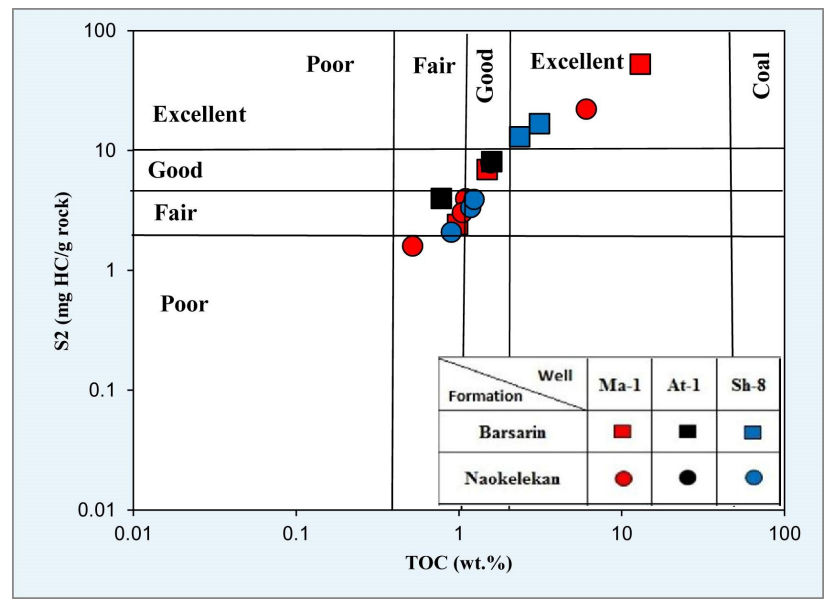

Figure 7: Plot of Pyrolysis $S_{2}$ versus Total Organic Carbon (TOC) showing generative source rock potential of Naokelekan and Barsarin formations

possibly due to the reducing environment at the time of the deposition of the source rock [22].

The Carbon Preference Index (CPI) is used as an indicator for maturity [15] CPI $=2\left(\mathrm{C}_{23}+\mathrm{C}_{25}+\mathrm{C}_{27}+\mathrm{C}_{29}\right) /\left[\mathrm{C}_{22}+\right.$ $\left.2\left(\mathrm{C}_{24}+\mathrm{C}_{26}+\mathrm{C}_{28}\right)+\mathrm{C}_{30}\right]$. Early researches maintained that immature source rocks often had high CPI values of $>1.5$, 
Table 3: Gas Chromatograph/Mass Spectrometry coupled with Isotope data of Naokelekan and Barsarin formations cutting samples

\begin{tabular}{ccccccccccccc}
\hline $\begin{array}{c}\text { Well } \\
\text { name }\end{array}$ & Formation & $\begin{array}{c}\text { Depth } \\
(\mathrm{m})\end{array}$ & $\delta_{\text {Sat }}^{13} \% 0$ & $\delta_{\text {Aro }}^{13} \%$ & $\mathrm{CV}$ & $\mathrm{Pr} / \mathrm{Ph}$ & $\begin{array}{c}\mathrm{Pr} / \mathrm{n}- \\
\mathrm{C}_{17}\end{array}$ & $\begin{array}{c}\mathrm{Ph} / \mathrm{n}- \\
\mathrm{C}_{18}\end{array}$ & $\mathrm{CPI}$ & $\mathrm{C}_{27} \%$ & $\mathrm{C}_{28} \%$ & $\mathrm{C}_{29} \%$ \\
\hline Ma-1 & Barsarin & 2397 & & & & 0.87 & 0.16 & 0.24 & 0.96 & & & \\
& Naokelekan & 2484 & -27.9 & -27.7 & -2.55 & 0.82 & 0.24 & 0.30 & 0.97 & 53.2 & 14.7 & 32.1 \\
At-1 & Barsarin & 1160 & -28.7 & -28.8 & -2.98 & 0.32 & 0.40 & 0.95 & 0.91 & 33.7 & 16.4 & 49.9 \\
& Naokelekan & 1210 & -28.6 & -28.2 & -1.89 & 0.37 & 0.34 & 0.72 & 0.92 & 54.5 & 16.0 & 29.5 \\
Sh-8 & Barsarin & 1509 & -28.3 & -28.0 & -2.21 & 0.44 & 0.33 & 0.56 & 1.04 & 49.9 & 15.4 & 34.7 \\
& Naokelekan & 1569 & -27.7 & -27.7 & -3.06 & 1.04 & 0.32 & 0.36 & 1.28 & 56.6 & 15.2 & 28.2 \\
\hline
\end{tabular}

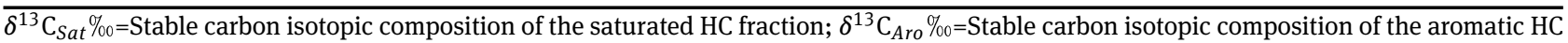
fraction; $\mathrm{C}_{27} \%=100 \times \mathrm{C}_{27} \mathrm{R} /\left(\mathrm{C}_{27} \mathrm{R}+\mathrm{C}_{28} \mathrm{R}+\mathrm{C}_{29} \mathrm{R}\right) ; \mathrm{C}_{28} \%=100 \times \mathrm{C}_{28} \mathrm{R} /\left(\mathrm{C}_{27} \mathrm{R}+\mathrm{C}_{28} \mathrm{R}+\mathrm{C}_{29} \mathrm{R}\right) ; \mathrm{C}_{29} \%=100 \times \mathrm{C}_{29} \mathrm{R} /\left(\mathrm{C}_{27} \mathrm{R}+\mathrm{C}_{28} \mathrm{R}+\mathrm{C}_{29} \mathrm{R}\right)$

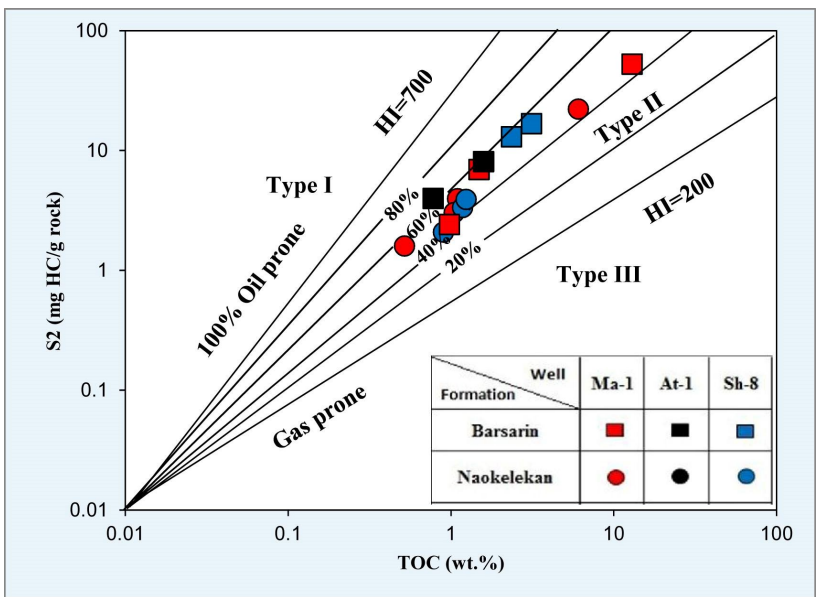

Figure 8: Plot of Total Organic Carbon (TOC) versus pyrolysis $\mathrm{S}_{2}$ shows the kerogen type for samples from Naokelekan and Barsarin formations. It also indicates whether the kerogen is oil or gas prone

whereas those of oils were invariably $<1.2^{[23]}$.e.g., mature source rocks have CPI values of $0.8<\mathrm{CPI}<1.2$, [19].

The Naokelekan and Barsarin formations in the three wells have low $\mathrm{Pr} / \mathrm{Ph}$ values of (0.37-1.04) and (0.32-0.87) respectively, indicating an anoxic, reduced marine carbonate depositional environment [24], (Figure 9). This conclusion has been noted by [25] at Miran-2 well, Miran oil field, NE Iraq. The $\mathrm{Pr} / \mathrm{n}-\mathrm{C}_{17}$ ratio is helpful for discriminating $\mathrm{OM}$ that formed under marine environment $<0.5$, from those formed in swamp environment $>1.0$, [26]. Lower values of $\mathrm{Ph} / \mathrm{n}-\mathrm{C}_{17}$, and $\mathrm{Pr} / \mathrm{n}-\mathrm{C}_{18}$ indicate marine source rock bearing Type-II kerogen [27].

The $\mathrm{Pr} / \mathrm{n}-\mathrm{C}_{17}, \mathrm{Ph} / \mathrm{n}-\mathrm{C}_{18}$ ratios of the six extract samples for the Naokelekan and Barsarin formations are 0.24$0.34 ; 0.30-0.72$ and $0.16-0.40 ; 0.24-0.95$, respectively (Table 3 ), indicating that the extracted bitumens were derived from a carbonate-rich-source rock, deposited in an anoxic marine environment and also appear to be medium to low biodegraded (Figure 10). The CPI of the extracts of both studied formations are $>0.80$ and $<1.20$ indicating marine source at the maturation stage, albeit with an exception of Naokelekan Formation sample in Sh-8 well with CPI value of 1.28 indicating immature stage (Table 3 ).

\subsection{Carbon isotopes composition $\left(\delta^{13} \mathrm{C} \%\right.$ )}

The isotope composition of the extracted bitumen (saturates and aromatics) can be used to distinguish between terrigenous and marine depositional environments by applying a mathematical relation known as Canonical Variable (CV) given by [28], stated as, $\mathrm{CV}=-2.53 \delta^{13} \mathrm{C}_{\text {Sat }}+$ $2.22 \delta^{13} \mathrm{C}_{\text {Aro }}-11.65$. The $\mathrm{CV}$ value of $>0.47$ mostly indicates terrigenous organic matter, whereas $<0.47$ indicates predominantly marine organic source [28]. The calculated CV for the studied extracts ranges from - 3.06 to -1.89 indicating prevalent marine environment (Table 3 ).

On the other hand, values of carbon isotope for the saturates $\left(\delta^{13} \mathrm{C}_{S a t}\right)$ and aromatics $\left(\delta^{13} \mathrm{C}_{A r o}\right)$ for five rock extract samples, belonging to Naokelekan and Barsarin formations, range from -28.7 to $-27.7 \%$ and -28.8 to $-27.7 \%$, respectively (Table 3). These values indicate a slight variation in isotopic composition of the extracted samples, owing to the maturation level between them [29]. It indicates that the $\mathrm{OM}$ of these formations was mainly derived from the marine source (Figure 11).

The GC-MS method was applied to monitor the ions with a mass/charge $(\mathrm{m} / \mathrm{z})$ ratio of 191 (terpanes) and 217 (steranes). Steranes are derived from sterols which are widely diffused in plants and microorganisms. The $\mathrm{C}_{27}$ and $\mathrm{C}_{28}$ sterols are most abundant in marine organisms and the $\mathrm{C}_{29}$ sterols in higher plants (Table 3). These general distributions in rock extracts can be used to indicate biological origin and depositional environment [23].

The ternary plot of regular steranes, expressed as $\mathrm{C}_{27} \%, \mathrm{C}_{28} \%$ and $\mathrm{C}_{29} \%$ is used to compare between the de- 

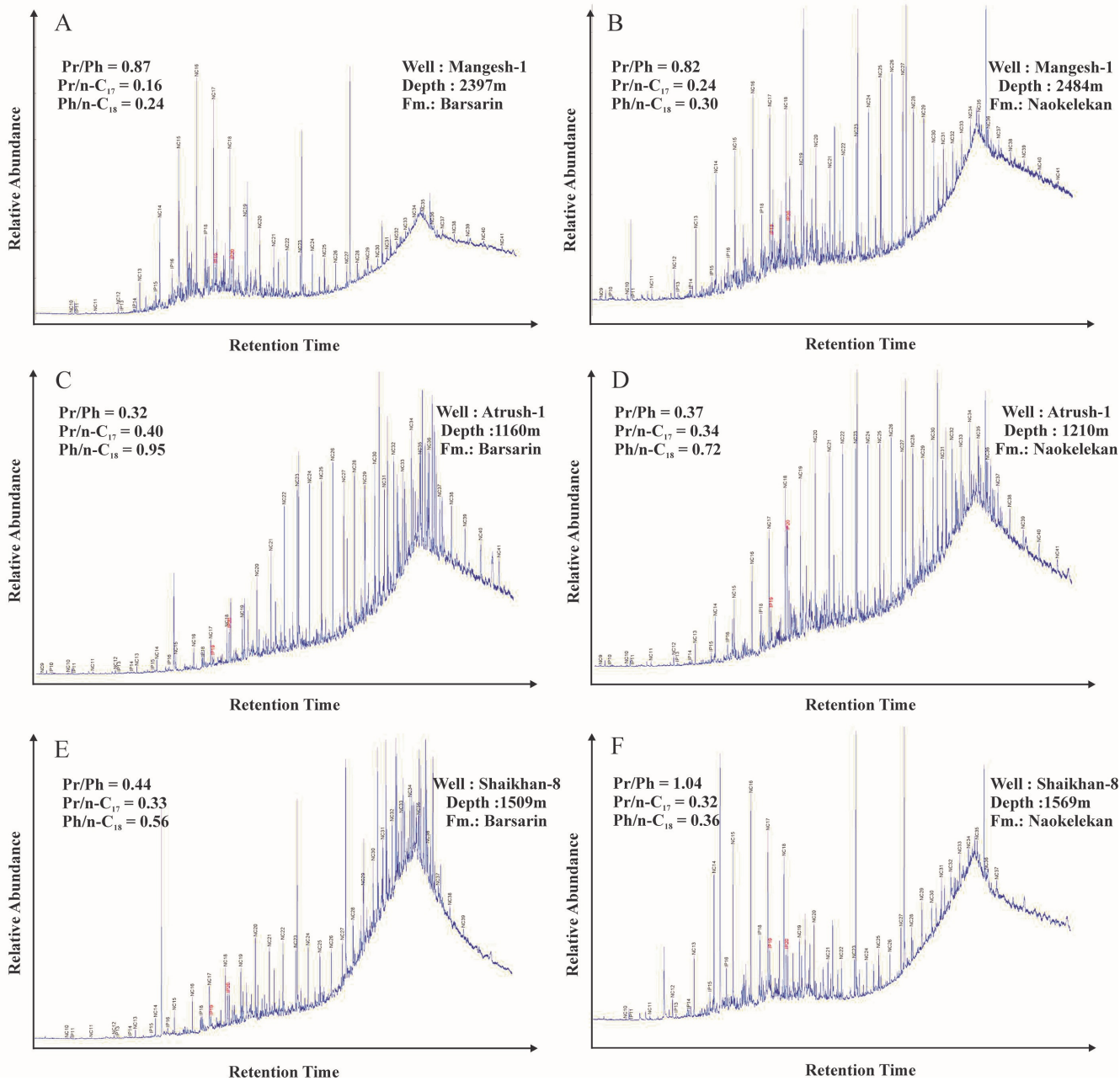

Figure 9: Gas chromatographs of extracted rock samples from Naokelekan (A,C,E) and Barsarin (B,D,F) formations, NW Iraqi-Kurdistan

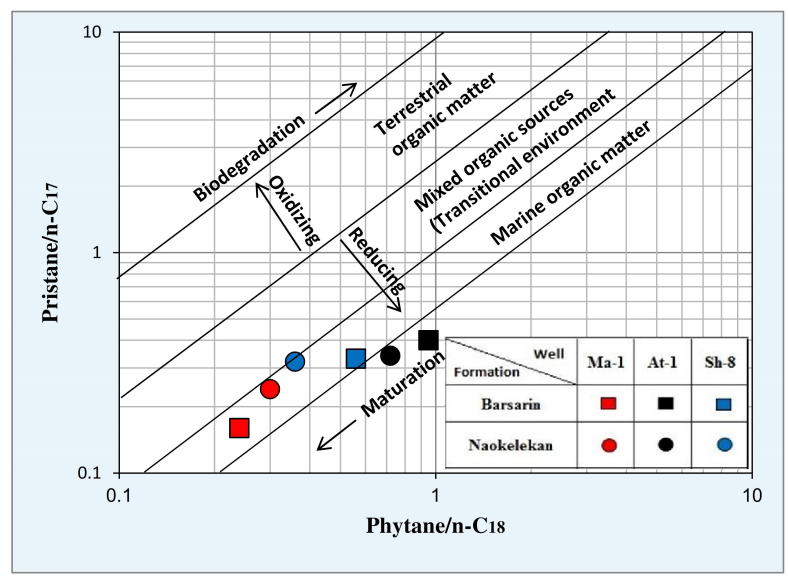

Figure 10: $\mathrm{Pr} / \mathrm{n}-\mathrm{C}_{17}$ versus $\mathrm{Ph} / \mathrm{n}-\mathrm{C}_{18}$ of extracts from Naokelekan and Barsarin formations in the studied wells

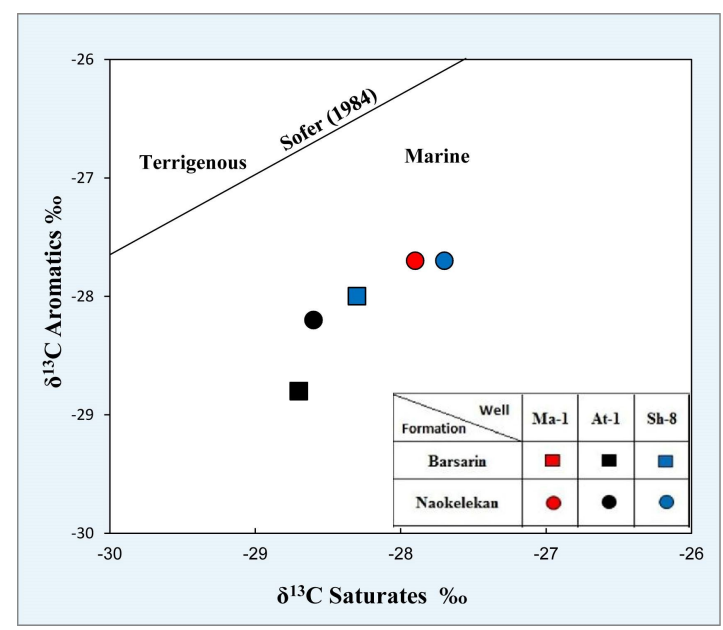

Figure 11: $\delta^{13} \mathrm{C}$ saturate versus $\delta^{13} \mathrm{C}$ aromatic cross plot for the analyzed extracts 
Well Mangesh-1

Naokelekan extrace

$2484 \mathrm{~m}$

GC/MS 217 steranes $\mathrm{C}_{27}$

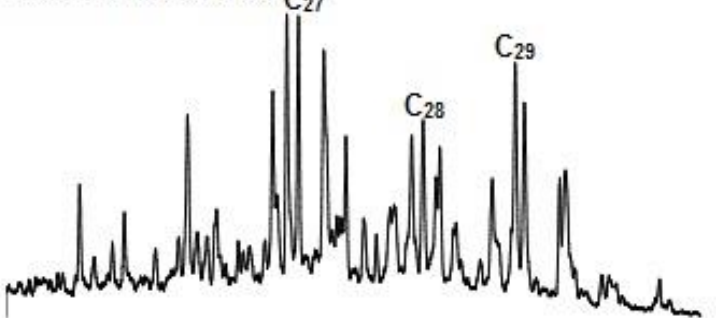

Well Atrush-1

Naokelekan extract

$1210 \mathrm{~m}$

GC/MS 217 steranes

Well Shaikhan-8

Naokelekan extract

$1569 \mathrm{~m}$

GC/MS 217 steranes

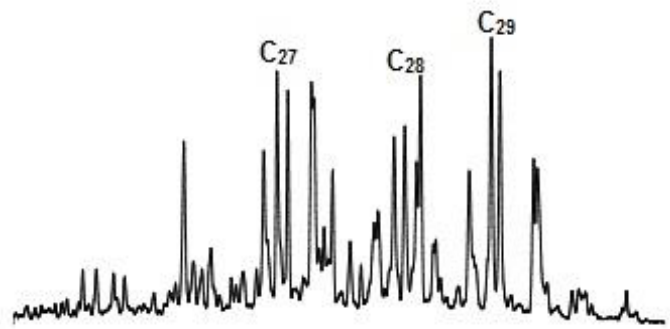

Well Atrush-1

Barsarin extract

$1160 \mathrm{~m}$

GC/MS 217 steranes

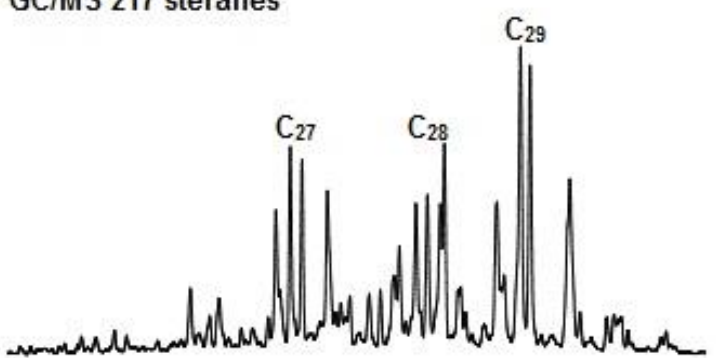

Well Shaikhan-8

Barsarin extract

1509m

GC/MS 217 steranes

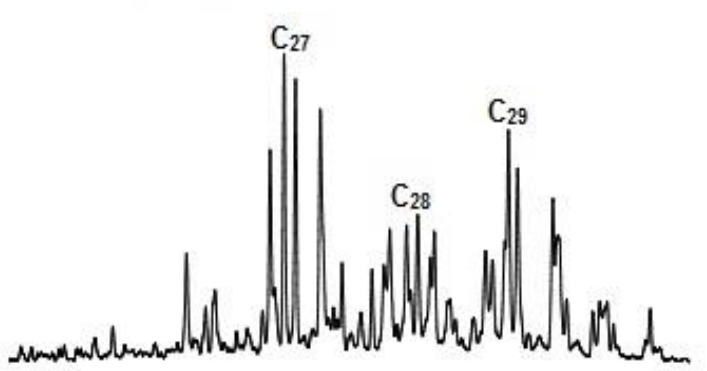

Figure 12: Mass chromatograms for steranes, $\mathrm{m} / \mathrm{z}$ 217, of extracted rock samples from Naokelekan and Barsarin formations of the studied wells 
positional environment and source materials for the studied samples. The resource of $\mathrm{C}_{27}$ steranes is of marine origin, and that of $\mathrm{C}_{29}$ steranes is mainly from advanced plants, whereas $\mathrm{C}_{28}$ steranes consist of a mix of advanced plants and algae [15].

The samples extracted from Naokelekan and Barsarin formations are characterized by abundance of $\mathrm{C}_{27}$ over $\mathrm{C}_{28}$ and $\mathrm{C}_{29}$ that was deposited exclusively under marine environment (Figures 12, 13).

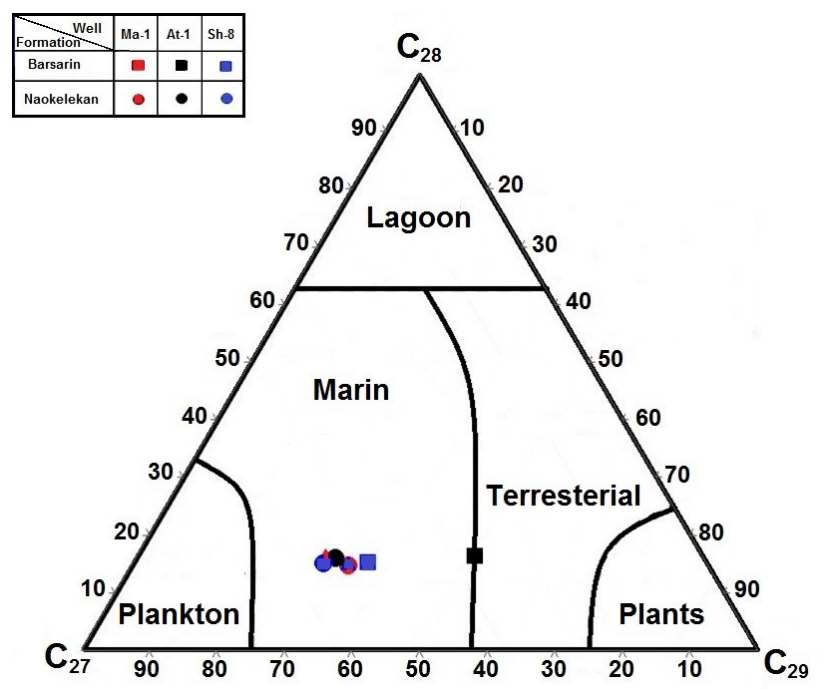

Figure 13: Steranes ternary diagram of $\mathrm{C}_{27} \%, \mathrm{C}_{28} \%$ and $\mathrm{C}_{29} \%$ concerning the selected extract samples using GC-MS m/z 217.

\section{Conclusion}

Following conclusions have been drawn from the geochemical and molecular characterization studies of the Late Jurassic Naokelekan and Barsarin formations samples from Ma-1, At-1, and Sh-8 wells in the northwestern Iraq that,

1. The OM in the Naokelekan Formation is mainly of Type II/III, whereas that of Barsarin Formation is dominantly, Type II.

2. The TOC contents ranging from 0.52 to $6.07 \mathrm{wt} \%(1.7$ wt $\%$, av.) and 0.78 to $13.00 \mathrm{wt} \%$ (3.3 wt $\%$, av.) for the Naokelekan and Barsarin formations, respectively, indicate that they have good source rock potential.

3. The $\mathrm{OM}$ in the sediments of Naokelekan and Barsarin formations were deposited in an anoxic environment, as revealed by $\mathrm{Pr} / \mathrm{Ph}, \mathrm{Pr} / \mathrm{n}-\mathrm{C}_{17}$ and $\mathrm{Ph} / \mathrm{n}$ -
$\mathrm{C}_{18}$ ratios, and they also appear to be medium to low biodegraded.

4. Carbon isotopic ratios of the saturate and aromatic fractions of the extracted samples from ternary plot of regular steranes of $\mathrm{C}_{27} \%, \mathrm{C}_{28} \%$ and $\mathrm{C}_{29} \%$, reveals that the $\mathrm{OM}$ in Naokelekan and Barsarin formations were derived mainly from the marine environment.

Acknowledgement: The authors would like to thank StratoChem Laboratories, New Maadi, Cairo, Egypt for their technical support. Thanks are also extended to the Ministry of Natural Resources - Geological Survey in Erbil for providing cutting samples. Many thanks for Prof. Dr. Yawooz A. Kettanah, Duhok University, for revising the manuscript.

\section{References}

[1] Jassim S.Z., Goff J.C., Geology of Iraq. Published by Dolin, Prague and Moravian Museum, Brno, 2006

[2] Aqrawi A.A.M., Goff J.C., Horbury A.D., Sadooni F.N., The petroleum geology of Iraq. Scientific Press Ltd, Beacon Field, UK, 2010

[3] Al-Naqib S.O., Geology of Atrush area. MSc thesis, University of Mosul, Iraq, 1980

[4] Al-Azzawi N.K., Hamdoon A.N., Structure and Geomorphology of Shaikhan Anticline-Northern Iraq. INJES, 2008, 8, 54-63

[5] Bellen R.C., Dunnington H.V., Wetzel R., Morton D., Lexique Stratigraphique Internal Asie, Iraq. International Geological Congress, Fasc. 10a, Paris: International Commission on Stratigraphy (in French), 1959

[6] Abdula R.A., Balaky S.M., Nourmohamadi M.S., Piroui M., Microfacies analysis and depositional environment of the Sargelu Formation (Middle Jurassic) from Kurdistan Region, northern Iraq. Donn J. of Geol. Min. Res., 2015, 1, 1-26

[7] Salae A.T.S., Stratigraphy and sedimentology of the Upper Jurassic succession Northern Iraq. MSc thesis, University of Baghdad, Iraq, 2001

[8] Al-Ameri T.K., Al-Nagshbandi S.F., Age assessments and palynofacies of the Jurassic oil source rocks succession of North Iraq. Arab J. Giosci, 2015, 8, 759-771

[9] Abdula R.A., Stratigraphy and Lithology of Naokelekan Formation in Iraqi Kurdistan. IJES, 2016, 5, 7-17

[10] Abdula R.A., Source Rock Assessment of Naokelekan Formation in Iraqi Kurdistan. JZS, 2017, 19, 103-124

[11] El Diasty W.S., El Beialy S.Y., Peters K.E., Batten D.J., AlBeyati F.M., Mahdi A.Q., Haseeb, M.T., Organic geochemistry of the Middle-Upper Jurassic Naokelekan Formation in the Ajil and Balad oil fields, northern Iraq. JPSE, 2018, 350-362, DOI: 10.1016/j.petrol.2018.03.031

[12] Ditmar V., Team I.S., Geological conditions and hydrocarbon prospects of the Republic of Iraq, northern and central parts. Iraq NOC Report, 1971

[13] Espitalie J., LaPorte J.L., Madec M., Marquis, F., LePlat P., Paulet J., Boutefeu A., Rapid method for source rock characterization and 
for determination of petroleum potential and degree of evolution. Oil Gas Sci. Technol, 1977, 32, 23-42

[14] Peters K.E., Cassa M.R., Applied source rock geochemistry. In: Magoon L.B., Dow W.G (Eds), The petroleum system-from source to trap. AAPG, Memoir, 1994, 93-120

[15] Peters K.E., Walters C.C., Moldowan J.M., The Biomarker guide, biomarkers and isotopes in petroleum exploration and earth history, Cambridge University Press, 2005

[16] Espitalie J., Madec M., Tissot, B., Role of mineral matrix in kerogen pyrolysis: influence on petroleum generation and migration. AAPG Bulletin, 1980, 64, 59-66

[17] Espitalie J., Deroo G., Marquis F., Rock-Eval pyrolysis and its applications. Revue De L Institut Francais Du Petrole, 1985, 40, 563-579

[18] Hunt J.M., Petroleum geochemistry and geology, $2^{\text {nd }}$ Edition. New York, W.H. Freeman, and Company, 1996

[19] Moldowan J.M., Seifert W.K., Gallegos E.J., Relationship between petroleum composition and depositional environment of petroleum source rocks. AAPG Bulletin, 1985, 69, 1255-1268

[20] Jarvie D.M., Tobey M.H., TOC, Rock-Eval and SR Analyzer Interpretive Guidelines. In Application Note 99-4. Humble Instruments and Services, In: Geochemical services Division Texas, 1999

[21] Abdula R.A., Organic geochemical assessment of Jurassic potential source rock from Zab-1 well, Iraqi Kurdistan, IBGM, 2016, 12, 53-64

[22] Ten Haven H.L., De Leeuw J.W., Rullkötter J., Damste J.S., Restricted utility of the pristane/phytane ratio as a palaeoenvironmental indicator. Nature 330, 1987, 641-643
[23] Jalees M.I., Tahira F., Saleem H., Study on the geochemical correlation of crude oils of Paleocene and Jurassic ages from the Potowar Indus Basin in northern Pakistan. Chinese J. of Geochem., 2010, 29, 82-93

[24] Tissot B.P., Welte D.H., Petroleum formation and occurrence, second ed. Springer -Verlag, Berlin, 1984

[25] Mohialdeen I.M.J., Mustafa K.A., Salih D.A., Sephton M.A., Saeed D.A., Biomarker analysis of the upper Jurassic Naokelekan and Barsarin formations in the Miran Well-2, Miran oil field, Kurdistan Region, Iraq. Arab J. Giosci., 2018, 11, DOI: 10.1007/s12517-0183405-x

[26] Osuji L.C., Antia B.C., Geochemical implication of some chemical fossils as indicators of petroleum source rocks. J. Appl. Sci. Environ. Mgt., 2005, 9, 45-49

[27] Obermajer M., Fowler M.G., Snowdon L.R., Depositional environment and oil generation in Ordovician source rocks from southwestern Ontario, Canada. Organic geochemical and petrological approach. AAPG Bulletin,1999, 83, 1426-1453

[28] Sofer Z., Stable carbon isotope compositions of crude oils: application to source depositional environments and petroleum alteration. AAPG Bulletin, 1984, 68, 31-49

[29] Demaison G., Huizinga B.J., Genetic classification of petroleum systems (1). AAPG Bulletin, 1991, 75,1626-164 